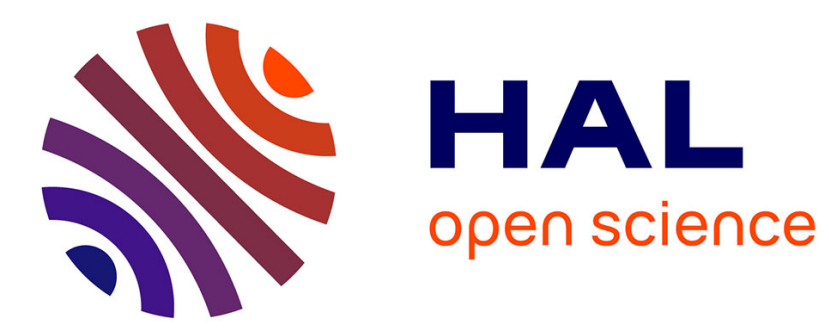

\title{
The Graphical Performation of a Public Space. The Subway Signs and their Scripts
}

Jérôme Denis, David Pontille

\section{To cite this version:}

Jérôme Denis, David Pontille. The Graphical Performation of a Public Space. The Subway Signs and their Scripts. Giovanna Sonda, Claudio Coletta, Francesco Gabbi. Urban Plots, Organizing Cities, Ashgate, pp.11-22, 2010. halshs-00536597

\section{HAL Id: halshs-00536597 https://shs.hal.science/halshs-00536597}

Submitted on 16 Nov 2010

HAL is a multi-disciplinary open access archive for the deposit and dissemination of scientific research documents, whether they are published or not. The documents may come from teaching and research institutions in France or abroad, or from public or private research centers.
L'archive ouverte pluridisciplinaire HAL, est destinée au dépôt et à la diffusion de documents scientifiques de niveau recherche, publiés ou non, émanant des établissements d'enseignement et de recherche français ou étrangers, des laboratoires publics ou privés. 


\title{
The Graphical Performation of a Public Space The Subway Signs and their Scripts*
}

\author{
Jérôme DENIS \\ LTCI (UMR5141) CNRS - Telecom ParisTech \\ Département Sciences Économiques et Sociales \\ jerome.denis@telecom-paristech.fr \\ David PONTILLE \\ IIAC - CNRS (UMR 8177) / EHESS (LC 12) \\ Équipe «Anthropologie de l'écriture » \\ pontille@ehess.fr
}

(2010) in G. Sonda, C. Coletta and F. Gabbi (eds.) Urban Plots, Organizing Cities, London, Ashgate, p. 11-22.

\footnotetext{
* This research is part of a collective project entitled 'Ecologies and Politics of Writing' (Département Sciences Économiques et Sociales, LTCI (UMR 5141) CNRS, Telecom ParisTech and Équipe Anthropologie de l'écriture, IIAC (UMR 8177) CNRS-EHESS) and supported by the Agence Nationale de la Recherche, Grant $n^{\circ}$ ANR-05-BLAN-0272-02. We gratefully acknowledge the people from the Régie Autonome des Transports Parisiens (RATP) for their active cooperation and the time they devoted to this study. We also thank Claudio Coletta, Francesco Gabbi and Giovanna Sonda for their willingness to make this book possible and their useful remarks on a previous version of this chapter.
} 


\section{Introduction}

Amid the deep transformations that cities have known in the last decades, the increase of mobility practices has played a central role (Amin and Thrift 2002). As a main feature of contemporary capitalism, it notably contributes to the emergence of new forms of exchange (Kellerman 2006 ; Urry 2007), which strongly articulate spatial configurations and informational devices (Lash and Urry 1994). In modern urban spaces there is no distinction between, on the one hand, the 'virtual' world of information and the circulation of a so-called immaterial knowledge, and on the other hand, the 'real' world in which bodies move and material constraints are plenty. New information and communication technologies take a great part in the day-to-day organization of cities.

Actually, the articulation between places and information is not new. As Latour and Hermant (1998) showed about Paris, urban spaces are both material and informational. The city is 'intellectual' (Simmel 1989), it holds plenty of signs and inscriptions among which some were in place long before the emergence of the new technologies of information and communication (Petrucci 1993). The public display of signs is inherent to the organizing process of urban settings: cities are made of semiotic landscapes.

Numerous urban signs are notably a matter of wayfinding. They provide a whole graphical layer for the accountability of places and the everyday organization of public settings. Street nameplates, traffic lights or signboards inform the passerby of its own location in the city ('this' neighborhood, 'this' street) and give indications about the suitable behavior she had to adopt ('stop here', 'turn left'). By marking sites, giving places a name, designating directions, these signs are what H. Garfinkel (1996) terms 'territorial organizational things'. They produce an ordering of the city within which

'practitioners are required to read descriptive accounts alternately as instructions. They do so occupationally, and as skilled matter of course, as vulgarly competent, specifically ordinary, and unremarkable worksite-specific practices. These are chained bodily and chiasmically to places, spaces, architectures, equipment, instruments, and timing'. (Garfinkel 1996: 19)

In this chapter, we will study such an ordering process from an actor-network theory perspective. The strength of ANT is to enlarge ethnomethodology's program, and its definition of social order as situated accomplishments, to non-humans (Latour 2005b). Agency is always distributed between people, artifacts, and other entities such as principles or rules (Cooren 2004). According to this model, collectives as nations or organizations arise from heterogeneous assemblages (Latour and Weibel 2005), and cities are not organized 'upstream', nor ordered by invisible forces. Urban spaces are the result of a continuous process carried out by day-to-day practices and mundane objects (Farias and Bender 2010). Performation, as Latour (2005b) puts it, is a useful notion to describe such a process. It insists on the dynamic of organizing and the necessity for collective entities to be maintained day after day. Furthermore, the notion offers a multilateral view: performation processes concern sites as well as their inhabitants whose practices and attitudes are constantly shaped by their environment. The signboards or the street nameplates can thus be seen as utter components of the performation of modern public spaces. Urban signs both order physical spaces and configure the action of their dwellers.

The role of signs in the ordering process of places has already been stressed in two kinds of settings: airports and supermarkets. For the first ones, G. Fuller showed that the standardization of displayed arrows and names produces a hybrid setting within which 'the distinction between the building and its signs, between the text and the territory, becomes indistinct' (Fuller 2002: 236). With the airport's signage, travelers are no more explorers: invited to follow the directions of a 'familiar authority', they are transformed into navigators. Within supermarkets, F. Cochoy and C. Grandclément (2005) showed how things such as logos, price labels, and nutrition facts tables are key features of the consumers' choice conditions of felicity. Both the spatial configuration of shelves and these various signs 
displayed on products' packagings have transformed the modern customers into homo œconomicus.

Airports and supermarkets are 'non-places' (Augé 1995): they are mainly auto-referential and their organization is focused on very specific concerns. On the contrary, urban spaces are highly heterogeneous. Their graphical ordering deals with issues that largely overflow flux management or choice improvement. In this chapter, we tackle such a complexity and try to understand the way urban signs confer specific positions to the dwellers in public spaces.

\section{Subway signs in Paris}

We will focus on the case of subway signs, using the results of an ethnographical fieldwork within the Régie Autonome des Transports Parisiens (RATP). In Paris, subway signs became a central issue in the beginning of the 1990s. At that time, a team of specialists (designers, cartographers and architects) was gathered to reconsider the whole subway signs organization. Surveys, field studies and experiments were conducted. That resulted in the creation of a complete wayfinding system (a 'signage', signalétique in French) and the redaction of a particularly ambitious policy. For the first time, the content, the shape, the size, the colors and the emplacement of subway signs have been standardized and detailed in extremely precise guidelines.

In doing so, the RATP established a real 'writing policy' (Foucault 1977) that deeply transformed subway spaces. Its main idea was to provide to riders as many on-the-spot instructions as they need to successfully 'use' the transportation network:

An electric iron, if there's nothing written on it, if there are no instructions on it, well... one does not know how it works. Here, it is the same: there are people who are moving, there are all these different spaces, one does not see what is happening behind, so our choice was to include instructions within each station. (L.T., Responsible for Signage Normalization, RATP)

There is of course an important issue here about what riders 'need', and more generally about who they are. Our aim is to discover which figures of users such a project conveys, that is, to identify the kind of riders this new graphical organization of subway space supposes. To understand how signage performs a specific public space, we will study it as a technology in which users' representations are inscribed. Thus, we follow S. Woolgar (1991) when he writes that innovation processes are 'configuring the user' as much as the technology. Moreover, we adopt the position of M. Akrich (1992) who showed that the innovation process could be compared to the writing of a 'script' that attributes tasks and positions to people and things, and organizes relations between them. As Akrich puts it, 'technical objects define actors, the space in which they move, and the ways in which they interact' (p. 216). This approach is extremely useful to analyze mundane graphical devices such as wayfinding systems because, for once, it allows to go backstage and surface the work carried out behind signboards. By studying the riders' representations inscribed within signage, we can identify the behaviors supposed to take place in subway spaces, and shed the light on the 'framework of action' (Akrich 1992: 208) that the Parisian policy of subway signs supports.

We developed a twofold methodological approach. First, we focused on internal narratives that accompany the signage policy. We conducted thorough interviews with RATP employees from the signage design and normalization department, and we systematically gathered documents that present the signage policy: the guidelines themselves, but also information leaflets, the slides of a presentation performed within the organization to announce the new signage, and articles of internal journals. If this set of data gives us access to the vocabulary used both to describe the great principles of the policy and to detail the subway signs' new organization, it also contains numerous assertions about the riders, their 'needs' and the ways they are supposed to use the new wayfinding system. 
Second, we tried to understand what it takes to follow the signage scripts in practical terms, that is, to adopt specific positions within subway spaces. In order to fully experience the scripts as frameworks of action, we had to reduce wayfinding to the sole use of subway signs, whereas ordinary riders always mobilize heterogeneous resources to find their way (Lacoste 1997 ; Ingold 2000). Therefore, we elaborated a phenomenological experimentation that consisted in the accomplishment of real rides within the Parisian subway system, during which we systematically gathered a picture and our comments for each board, sticker and poster we relied on to reach our destination. Since the use and the signification of the signage components were sometimes at the center of on-the-spot debates, we regularly confronted our own interpretations to take decisions and pursue our trip. This experiment offers two advantages. First, photographs are particularly useful to study visible materials (Wagner 2006). In the case of signage, the strict 'shooting script' we followed (Suchar 2007) offered a means to put all the signs mobilized during a ride on the same level and to force us, as researchers, to question each of them. Second, noting our comments and debates was a rich way to surface interpretation processes, which might have remained tacit if we conducted such experiences alone.

Thus, following the trail of their scripts, we studied the Parisian subway signs as organizational artifacts: we both gathered the narratives about the riders' needs and attitudes that are inscribed in them, and discovered the practical tasks their situated uses require. We identified four distinct scripts that we will detail in the next sections: information, planification, problem solving and reaction. For each one of them, we will precise the riders' definition it relies on, the type of signs that are supposed to carry it, and what it really takes in situation to follow it, that is, what one has to do to effectively become an informed rider, a planner, a problem solver or a reactive entity.

\section{Information}

In the first script we identified, the signage is conceived of as a set of tools that inform the riders. The informed rider is a familiar figure within the RATP, which has been striving for long to provide a convenient amount of information to its users. Yet, for years, the issue of information and the figure of the informed rider used to refer almost exclusively to perturbed situations. It was a crucial dimension for the service's quality that riders had to be informed each time the normal conditions of network were disturbed. In other terms, people were supposed to become informed riders only when things went wrong in the transportation network.

With the new signage policy, the informational script has been noticeably enlarged. The figure of the rider who seeks help during perturbations has been gradually completed with another one who needs to be informed continuously. Within the internal documents and during the interviews such an ordinary informed rider is omnipresent and the need for information appears as an essential dimension in the designers' definitions of subway users. But information is not mobilized as an abstract notion to describe all kinds of situations and everything subway signs have to provide. It is tightly attached to the notion of control. The informed rider is a person who tries to gain more control on the mundane circumstances of her rides.

We also have to provide riders a control of time in the course of their rides, by informing them [...] about waiting time according to real traffic conditions. (RATP 1993: 14)

Such a script clearly takes part in the larger historical trend of the formation of technological societies. Signage here goes with the numerous devices that transform the modes of government from surveillance to communication, where government itself 'relies on the existence of the informed citizen' (Barry 2001: 48). Providing information within subway spaces is a way to perform an informed rider who can fully control her displacements. 
Signboards that provide information are specific ones. They are discursive, that is, they are designed to provide 'messages' to the riders. For example, in certain halls posters can be found that list the names of stations currently concerned by renovation works and unaccessible during a particular period. Recently, electronic real-time devices have also been put up on platforms in order to display the time remaining until the next two trains. Here, signs are mainly texts. They perform a discursive ordering of riders' environment by letting them know that 'this station is unavailable', 'the next train will be here in 8 minutes'.

Within subway spaces, to be informed, the rider has to read. This sounds obvious, but is not so: the circulation of information is never a straight and transparent operation. To read a poster's text is one thing; to make up a piece of information (and thus a resource for action) from what it is written is another. To become an informed user, not only the rider has to decipher the linguistic content of a signboard or a poster, but she also has to match this content with the actual situation (dates, places, etc.). For example, if a board displays the schedule of first and last trains according to weekdays, weekends and holidays, one has to align two things to really be informed: what the board reads and the current day and time.

Furthermore, because all information does not appear in a sole board, to become informed, the rider generally has to forge a chain of multiple readings in the course of her ride, from one discursive sign to another. In other terms, the rider does not have to simply grasp information, as it would be 'naturally' displayed in the surroundings. As we did several times during our rides, she has to articulate different texts and messages with her own situation, in order to produce a comprehensive informational resource.

\section{Planification}

The second script draws the figure of a pretty different rider. Here, she is staged as a person who needs to prepare her ride: she's a planner. The figure points to two distinctive dimensions. The first one is anticipation. As a planner, the rider is considered a strategic human being who makes rational projections for her future actions. The second dimension is calculation. In the documents or interviews which mention such a rider, she is conceived of as someone who collects different kind of facts (station names, lines number, connections...) and computes all these data to produce an operative scenario. The planner translates her displacement ('to go to this particular place') into a point-by-point itinerary, using several calculative operations.

At home or at work, riders have a lot of tools at their disposal to plan their trips before they enter into a subway station. But the RATP signage policy aims to provide specific devices that can be consulted in situ. These devices, such as maps or timetables, display abstract representations. They offer a simplified panoramic view of the network that makes its spatial characteristics (stations geographical position, trains route) and its temporal ones (timetables and frequency of trains) commensurable. These signage components perform a calculable setting. For example, timetables support the organization of a trip by anticipating the time of departure and the potential connections to reach the final destination.

Although one could think so, such devices are not identifiable to 'cognitive artifacts' (Norman 1991): they do not produce calculation themselves, contrary to the altitude alert system that E. Hutchins (1995b) described for example. The planification work largely remains on the rider's side.

A map is still an information system that forces the person to work. [...] The map tells you everything and nothing at the same time, that is: you have to find the map's instructions, you have to find your departure point, you have to find your arrival point and then manage to understand everything that we put in the map... to see the connections, and this and that... (Q.W., Responsible for Cartography Department, RATP)

During our phenomenological experimentation, we decided to do unusual rides in regard to our regular experience of the Parisian subway network. These cases always began in front of 
a map by struggling with the multitude of signs in order to anticipate the lines and connections that would be relevant to reach the final destination we chose.

Such a script puts the rider in the same position that the person L. Suchman imagined for her well-known example of rapids' run, who 'sits for a while above the falls and plans [her] descent' (Suchman 2007: 72). The location of the specific signage components, supposed to equip the rider planner, plays an important role to perform such an anticipatory operation. Timetables and maps are essentially displayed within halls and not corridors or staircases.

However, subway stations are not rapids. First, planning cannot be done from a geographical position that overhangs the entire landscape. In subway systems, the rider is never 'above the falls', she can never watch the whole settings of her future displacements. For planning, she faces graphical representations from which she gathers specific kinds of instructions. As opposed to the canoe driver, she has no means to plan 'I'll get as far over to the left as possible, try to make it between those two large rocks' (Suchman 2007: 72). The rider only knows that she has to 'take line 2 towards Nation, change at Saint-Lazare for line 3 towards Pont de Levallois, and stop at Wagram'.

Second, because of the semiotic nature of planning devices, the rider cannot completely 'abandon the plan and fall back on whatever embodied skills' (Suchman 2007: 72). When in corridors, she will no longer have access to the rich representation of maps and timetables. In a way, the signage radicalizes the frontier between places (and times) where riders can plan and places where they have to move. The success of their rides depends then both on the memorization of the instructions that compose their plans and on their ability to locally understand the indexicality of each sign.

\section{Problem solving}

The third script involves a rider who has problems to solve. Here, the figure is drawn from a micro-level perspective and refers to the description of each ride as a series of choices to be made. But these choices are more like dilemmas than options. The rides are not peaceful and the problem solver figure is mainly a worried person. Subway spaces are presented as real labyrinths that put the riders in a state of maximal uncertainty. The problem solver, as she moves, is assailed with questions:

Where can I make a phone call? Where can I buy a ticket? Which bus should I Take? On her path, at each moment, the rider wonders. (RATP 1997: 2)

The aim of signage here is to give to the rider every possible means to get out of what is presented as her 'natural' state of indecision. Thus, if the figure of problem solver is imported from the cognitive sciences where it is central (Simon and Kaplan 1989), it is actually far from their mentalist perspective. For the signage designers, the graphical objects put in the environment are conceived of as external resources that should help the rider in search for a solution. Here, the problem-solving operations are then inscribed within a large cognitive system. Cognitive tasks are distributed between humans and artifacts (Hutchins 1995a) and do not depend on a sole individual engaged in a self-reflexive deliberation. As the responsible for signage normalization told us, within subway stations, the signage and the riders are supposed to 'work hand in hand'. If we focus on the figure of the rider, that means that she is performed as an equipped person: confronted to a multitude of choices, she is supposed to take a significant advantage by delegating some solutions to signboards, instead of thinking by herself.

The signs that support this figure are mainly the directional ones. They display both places' identifications (lines' numbers, destinations, streets' names) and arrows. They play a crucial role in the ordering of spaces by marking the links between sites. Their presence performs a hybrid environment (Fuller 2002) that is as well architectural as cognitive: a setting that supports decision-making. In a way, associated to the figure of problem solver, what the 
signage does to the subway spaces can be compared to what F. Cochoy (2004) showed about the packaging in grocery stores: not only it provides the resources to decide but it performs the conditions for the choice itself.

[With signage], at any time one is confronted to a choice that divides the universe in two parts: what can be reached by turning left and what can be reached by turning right. Then, one direction of our system applies to half of the space and the other direction applies to the other half. (L.C., Information Systems \& Telecommunications Department, RATP)

But the felicity of such an 'equipped choice' setting cannot be understood with the sole vocabulary of the distributed cognition model. If signboards are clearly designed to become cognitive resources, they are, in the same time, constituted as constraints. In the performation process we try to describe here, both the environment and the riders are shaped. Not only is the rider invited to rely on various signs during her displacement; she is also invited to mobilize them in a certain manner. This is extremely clear for the problem solver figure for which some signs are designed in order to bypass any deciphering operation at a certain distance. Words that appear on them are made to be spot, not read:

The important thing is that a destination is a shape that I spot. That is: it is clear that 'Neuilly' and 'Chateau de Vincennes' cannot have the same shape. And to do this, we need to write in capital letters and lower-case letters on the one hand, and to reduce the letters height on the other hand, in order to obtain what's absolutely necessary to be seen, to be read when one stands from a certain distance and beyond the shape of words becomes imperative. (L.C., Information Systems \& Telecommunications Department, RATP)

This last point stresses an important feature of the problem solving script. During some parts of our rides, our choices have to be made not in deciphering messages but in spotting specific signs and recognizing 'outlines of drawn words' (RATP 2002: 15 [slides]). In order to become an equipped rider, one then has to leave some habits behind, which is a real competency. Here, one has to accept not to read.

\section{Reaction}

The last script defines the rider as a reactive entity. Neither in a position of control, nor in a situation of uncertainty, she is staged as a person who goes smoothly through corridors, halls and platforms, almost without thinking. She does not have any imperative for organizing her trip in advance and does not engage in self-reflexive deliberations. Intensely aware of the surroundings, she is mostly reactive. The rider is here driven by basic automatic reflexes:

No sooner seen than glimpsed... [...] All the signs that compose the new signage are taken at first glance. The repertoire is mostly constituted of signs that have existed for a long time within the RATP signage policy and that, modernized, provoke immediate user reflexes. (RATP 1997: 2)

Specific features of subway signs, such as materials and colors, are designed to support this reactive attitude. Some of them are generally inherited from a longer history than subway systems themselves. It is the case of certain colors, or shapes, that are used to operate a real 'semiotization' of the signboards. B. Fraenkel (2006) constituted this kind of conventional work as a key issue of her theory of writing acts: some actions can be fully inscribed in the material support. Here, colors and shapes support the differentiation between the boards and the identification of the distinct functions that are attributed to them. Such a semiotic investment relies on a standardization process. In order to accompany reactive movements, colors and shapes have to remain strictly the same all over the subway network. Because they perform a strongly ordered setting, they are key components of the stabilization of the space itself.

To become a reactive entity, the rider has to adopt an almost animalistic attitude within this stabilized surrounding. She has to restrict her way finding operations to sheer 'perceptive procedures' (Hutchins 1995b). By walking on corridors or platforms, she has to identify signs 
at first glance and at a great distance. For example, she can easily follow the 'exit' boards thanks to their glossy dark blue in Paris. In a way, she has to stop thinking and to use only her eyes, in order to delegate the control of her ride to the artifacts installed in the surroundings. In the course of our rides, we regularly adopted this reactive position, notably when we followed the color of the relevant line for the next connection. We only had to glimpse the color while moving and mainly focusing our attention on one of our stimulating theoretical debates.

In such a framework of action, each sign has to be grasped as a clue to go on and movement is performed in a series of perception/action sequences.

During the whole trip, signage should be followed as the best of guides. Signs take over one from another; one has simply to follow them in order to get to the city and to reach closer to her destination. (RATP, 1997: 2)

Thus, the rider must be able to engage in a step-by-step process, following one lower-level instruction after another, what the designers called an 'Ariadne's thread' (Wiart, Le Roux and Lomazzi 1998).

This form of engagement between the rider and her environment is close to what $\mathrm{C}$. Bessy and F. Chateauraynaud (1995) termed the 'régime d'emprise', where people and things are tightly bounded, which cancels any human pretension to objectivization. To become a reactive entity, the rider has to accept this dependency to the surroundings. She then reaches a particular state that 'is characterized by the absence of rupture between entities [... and] leads to the impossibility of any kind of detachment' (Bessy and Chateauraynaud 1995: 263).

What is performed here is the seamless circulation of bodies through the network. The riders are configured as entities moved by the fluidity of traffic. From this point of view, the script is pretty different from the previous one where people are supposed to stop at each junction, even briefly, and make choices between options clearly exposed by the signage components. Even if both scripts involve a similar process of delegation to the environment, they perform two distinct rhythms of movement.

\section{Conclusion}

What have we learned from the details of Parisian signage scripts and from the analysis of the embodied practices they require? Above all, we showed that the accountability performed by subway signs is plural. We identified four different figures of riders: the informed one, who wants to control her trip and has to read messages; the planner, who anticipates the conditions of her ride and has to use calculation devices; the problem solver, who calms down her anxiety by finding clear options exposed on recognizable signboards; the reactive entity, who circulates smoothly by responding automatically to specific graphical features of the surroundings.

In the Parisian subway spaces, the rider is never performed only as a reader who would catch some meaning from various texts. Sometimes she is more 'active' (when she has to compute data to plan her trip), and sometimes more 'passive' (when she has to react automatically after perceiving the shape or the color of a signboard). Signage displays neither a text, nor a discourse. It is made of the 'a-signifying elements of time, space, rhythm, movement, bodies and so on' (Fuller 2002: 241).

Such a plurality strongly contrasts with the metaphor of reading that still has great resonance in the analysis of urban settings and where streets, squares, buildings, and cities themselves are supposed to be legible (Stierle 2001). This metaphor invites to study cities as texts and implicitly promotes a literate accountability. In contrast, we saw that designers strive to fit out a graphical accountability that relies on a wide range of actions. 
Interestingly, in designers' discourses, the riders' figures are never reduced to 'types' of riders or marketing targets. They neither mobilize ontological definitions of individual users, nor pretend to describe any kind of diversity within the population. The pluralistic accountability that the signage provides concerns each single rider. The same person may go throughout various frameworks in the course of a single trip. Generally, she actually has to do so.

Thanks to signage, plurality is a feature of the surroundings. However, it does not mean that every figure is supported anytime and everywhere. Precisely, the graphical ordering aimed to support the 'success' of rides is performed by the spatial and temporal distribution of the signs, and the riders' states they are intended to generate. Subway spaces are designed as pathways where the available resources for orientation change according to the section one goes through. Successful rides should be performed by the successive encounters between the riders' adequate states and the standardized signboards, that is, the progressive actualization of different scripts.

That is how the signage performs a public space: it ascribes states and positions to people according to the sites they cross. Such a performation process accomplishes a configuration, that is, an articulation between particular figurations of spaces and certain figures of riders. But while the first ones are in the hand of the designers and the placement workers (Denis and Pontille forthcoming), the second ones remain virtual. To be actualized, they have to be enacted on the spot by disciplined riders who, as the pedestrian in Paris described by Latour and Hermant (1998), go through one device to another, through one user's figure to another:

I'm not simply passing through Paris: the 'l' also passes through forms of action, regimes of intelligence that are virtually unrelated to one another. [...] From one second to the next different regimes of action relayed one another, leading me from one competence to the next. I'm neither in control nor without control: I'm formatted. I'm afforded possibilities for my existence, based on teeming devices scattered throughout the city. I go from one offer to the next. To progress a little further I grasp the small bit of program that others have stuck onto each device for me. (Latour and Hermant 1998, p. 68)

But, unlike to the various devices present in the streets that address different senses (hearing, sight, touch...), the signage confronts the riders to a sole kind of artifacts. Its plurality remains within the world of signs, and the regimes of action that it supposes are always a matter of gazes and visibility. In other terms, the graphical accountability provided by signage inscribes a politics of attention in public settings.

E. Goffman (1959) insisted on the human side of public spaces. He showed the importance of 'civil inattention' that occurs within cities, that is, the ability of people to be aware of others without conspicuously focusing on their movements and attitudes. The case of signage shows that non-humans can also become a crucial matter of concern in the organizing of public settings (Latour 2005a). To properly use the Parisian subway system, the riders have to be aware of numerous graphical artifacts. Dwelling in subway spaces requires, besides a civil attention, a graphic attention, which, as we showed, demands several specific cognitive skills. And not only have the riders to dispose of these skills: they also need to juggle with them, from one site to another, from one moment to another.

This politics of attention rests on the designers' desire to build an omnipresent graphical apparatus, meant to encompass all kinds of uses. Largely inspired by social theories that took part in Design Research and Human Computer Interaction Studies (such as 'situated action' and 'distributed cognition'), it performs a user-centric world. It is then highly individualistic. Even if signage is a form of public lettering, devoted to several people in the same time (Petrucci 1993), it actually provides an interface that each isolated person can use to navigate the world. The four scripts of the Parisian subway signs, which inscribe various ways to distribute some features of the human cognition within the surroundings, all require a 'face-to-face' relationship between a rider and the signage components. They clearly rely on 
an individual cognitive availability. In other terms, the Parisian signage is meant to equip a rider who could be all alone. By following the sole signboards directions she could still manage to find her way within the transportation network.

The Parisian signage thus performs a very specific public setting. In order to more precisely understand it, one can ask one of the favorite questions of the Actor-Network Theory: what is delegated in this artifact? We saw that signage is not representational. It then has nothing to do with the public display of matters of concern, that is, things we collectively consider (Latour 2005a). Actually, the signage operates a twofold delegation. Signs are meant to replace and, above all, expand the presence of employees of the carrier who could verbally help the riders. But they also replace the collective of co-present riders. From the designers' view, the fact that a rider asks for her way to another rider is considered as a failure. What is at stake with the omnipresence and the standardization of signboards is not public consciousness, but strictly personal guidance. It seems that this kind of individual gears are currently growing, with the success of numerous Global Positioning System (GPS) devices on the one hand and real-time information urban displays on the other. This twofold equipment, of people and places, perform public settings that are augmented with an informational layer, a whole interface, and that are evaluated in the sole terms of operability and efficiency. It sets the basis for public spaces where dwelling together counts less than successfully navigating side by side.

\section{Primary sources}

RATP 1993, Politique de l'information des voyageurs. Point sur la mise en œuvre, Annexe au Conseil d'Administration du 29 Octobre 1993.

RATP 1997, Signalétique multimodale. La RATP fait signe aux voyageurs, Document de présentation interne, Département des projets, Conception de l'information.

RATP 2002, La signalétique multimodale. Code des espaces voyageurs, Document de présentation interne.

Wiart, A., Le Roux, A. and Lomazzi, M. 1998, 'Signalétique, le nouveau fil d'Ariane', La vie du rail et des transports, no. 57, pp. 30-5.

\section{References}

Akrich, M. 1992. The de-scription of technical objects, in Shaping Technology/Building Society. Studies in Sociotechnical Change, edited by W. E. Bijker et J. Law. Cambridge, MA: MIT Press, 205-224.

Amin, A. and Thrift, N. 2002. Cities. Reimagining the urban. Cambridge: Blackwell.

Augé, M. 1995. Non-Places: Introduction to an Anthropology of Supermodernity. London: Verso.

Barry, A. 2001. Political Machines. Governing a Technological Society. New York: The Athlone Press.

Bessy, C. and Chateauraynaud, F. 1995. Experts et faussaires : pour une sociologie de la perception. Paris: Métailié.

Cochoy, F. 2004. Is the modern consumer a Buridan's donkey ? Product packaging and consumer choice, in Elusive Consumption, edited by K. Ekström et $\mathrm{H}$. Brembeck. Oxford and New York: Berg Publisher, 205-227.

Cochoy, F. and Grandclément, C. 2005. Publicizing Goldilocks' choice at the supermarket: the political work of product packaging, shopping carts, and shopping talk, in Making Things Public: Atmospheres of Democracy, edited by B. Latour et P. Weibel. Cambridge: MIT Press, 646-659. 
Cooren, F. 2004. Textual agency: how texts do things in organizational settings. Organization, 11(3), 373-393.

Denis, J. and Pontille, D. forthcoming. Placing Subway Signs. Practical Properties of Signs at Work. Visual Communication.

Farias, I. \& Bender, T. 2010. Urban assemblages. How Actor-Network Theory changes urban studies. New York: Routledge.

Foucault, M. 1977. Discipline and Punish. Harmondsworth: Penguin.

Fraenkel, B. 2006. Actes écrits, actes oraux: la performativité à l'épreuve de l'écriture. Études de Communication (29), 69-93.

Fuller, G. 2002. The arrow-directional semiotics: wayfinding in transit. Social Semiotics, 12 (3), 231-178.

Garfinkel, H. 1996. Ethnomethodology's program. Social Psychology Quarterly, 59 (1), 5-21.

Goffman, E. 1959. The Presentation of Self in Everyday Life. Anchor.

Hutchins, E. 1995a. Cognition in the Wild. Cambridge: MIT Press.

Hutchins, E. 1995b. How a cockpit remembers its speeds. Cognitive Science, 19, 265-288.

Ingold, T. 2000. The Perception of the Environment. New York: Routledge.

Kellerman, A. 2006. Personal Mobilities. New York: Routledge.

Lacoste, M. 1997. L'information à visage humain: la place des agents dans un système d'information-voyageurs, in Les traversées de la gare. Une méthode des trajets pour analyser l'information-voyageurs, edited by D. Bayart, A. Borzeix, M. Lacoste et J. Theureau. Paris: RATP, Département du développement, unité prospective., 25-81.

Lash, S. and Urry, J. 1994. Economies of Signs and Space. London: Sage.

Latour, B. 2005a. From realpolitik to dingopolitik or how to make things public, in Making Things Public: Atmospheres of Democracy, edited by B. Latour et P. Weibel. Cambridge: MIT Press, 14-41.

Latour, B. 2005b. Reassembling the Social: An Introduction to Actor-Network-Theory. Oxford: Oxford University Press.

Latour, B. and Hermant, É. 1998. Paris ville invisible. Paris: Les empêcheurs de penser en rond / La Découverte. English version available at: http://www.bruno-latour.fr/virtual/PARISINVISIBLE-GB.pdf [accessed: 22 October 2009].

Latour, B. and Weibel, P. (eds). 2005. Making Things Public: Atmospheres of Democracy. Cambridge, MIT Press.

Norman, D. 1991. Cognitive artifacts, in Designing Interaction: Psychology at the HumanComputer Interface, edited by J. M. Carroll. Cambridge: Cambridge University Press, 17-38.

Petrucci, A. 1993. Public Lettering. Script, Power, and Culture. Chicago: The University of Chicago Press.

Simmel, G. 1989. La ville, in Philosophie de la modernité, Paris: Payot, 169-199.

Simon, H. and Kaplan, C. 1989. Foundations of Cognitive Science. Cambridge: MIT Press.

Stierle, K. 2001. La Capitale des signes. Paris et son discours. Paris: Éditions de la Maison des Sciences de l'homme.

Suchar, C.S. 2007. Grounding visual sociology research in shooting scripts. Qualitative Sociology, 20 (1), 33-55.

Suchman, L. 2007. Human-Machine Reconfigurations. Plans and Situated Actions 2nd Edition. Cambridge: Cambridge University Press. 
Urry, J. 2007. Mobilities. Cambridge: Polity.

Wagner, J. 2006. Visible materials, visualised theory and images of social research. Visual Studies, 21(1), 55-69.

Woolgar, S. 1991. Configuring the user: The case of usability trials, in A Sociology of Monsters: Essays on Power, Technology and Domination, edited by J. Law. London: Routledge, 58-97. 